\title{
TREE STRUCTURE IN THE FOREST OF PINDO MIRADOR BIOLOGICAL STATION, PASTAZA, ECUADOR
}

\author{
Christopher Oswaldo Paredes Ulloa ${ }^{1 *}$, Jorge Ferro-Diaz ${ }^{2}$, Pablo Lozano Carpio ${ }^{3}$, Yulian Carrasco Rodríguez ${ }^{4}$.
}

\author{
1Universidad Estatal Amazónica, PhD Program in Forest Sciences, Puyo, Pastaza, Ecuador - e-mail: chris9enginer@gmail.com \\ ${ }^{2}$ Center for Research and Environmental Services, Investigations Department, Pinar del Río, Cuba - e-mail: jorge.ferro2011@ gmail.com \\ ${ }^{3}$ Universidad Estatal Amazónica, Investigations Department, Puyo, Pastaza, Ecuador - e-mail: pablo_lozanoc@ yahoo.com \\ ${ }_{3}^{3}$ Universidad de Pinar del Río, Forestry Department, Pinar del Río, Cuba - e-mail: yulianc84@ gmail.com
}

Received for publication: 30/07/2020 - Accepted for publication: 06/12/2020

\begin{abstract}
Resumo
Estrutura arbórea na floresta da Estação Biológica Pindo Mirador, Pastaza, Equador. O objetivo desta pesquisa foi caracterizar a estrutura arbórea da floresta perenifólia do Piemonte da estação biológica Pindo Mirador, Pastaza, Equador. Oito parcelas de 0,1 ha foram sistematicamente estabelecidas; todas as árvores foram medidas com D1. 30 do chão $\geq 10 \mathrm{~cm}$ e sua altura total. Os dados de abundância por espécies e parcelas, classes de diâmetro e faixas de altura foram tomados para serem analisados com estatística descritiva, e por meio de comparações não paramétricas de Kruskal-Wallis para verificar diferenças entre eles. A contribuição das espécies para a estrutura da floresta foi avaliada por meio da determinação de índices de diversidade estrutural, incluindo o Índice de Valor de Importância (IVI) das espécies e sua área basal. Os resultados mostram uma riqueza de 89 espécies pertencentes a 58 gêneros de 39 famílias, onde predominam árvores com diâmetros entre 10 e $20 \mathrm{~cm}$ e alturas entre 8 e $20 \mathrm{~m}$. Conclui-se que se trata de uma floresta relativamente homogênea, com elementos típicos da transição andino-amazônica, cuja estrutura vertical de vôo dominante é de piso médio ou sub-copado, moderadamente denso, dominado por árvores de Iriartea deltoidea Ruiz \& Pav., Alchornea latifolia Swartz, Hyeronima oblonga (Tul.) Müll. Arg. E Piptocoma discolor (Kunth) Pruski, que apresentam a maior incidência em sua estrutura.

Palavras-chave: Florestas em regeneração, dasometria, estrutura florestal, índices de diversidade.
\end{abstract}

\begin{abstract}
The objective of this research was to characterize the arboreal structure of the evergreen piedmont forest of the Pindo Mirador biological station, Pastaza, Ecuador. Eight plots of 0.1 ha were systematically established; all trees were measured with $\mathrm{D} 1.30$ from the floor $\geq 10 \mathrm{~cm}$, and its total height. The abundance data by species and plots, diameter classes and height ranges were taken to be analyzed with descriptive statistics, and by means of non-parametric Kruskal-Wallis comparisons to verify differences between them. The contribution of species to the structure of the forest was evaluated by determining indices of structural diversity, including the Importance Value Index (IVI) of species, and their basal area. The results show a richness of 89 species belonging to 58 genera from 39 families, where trees with diameters between 10 and $20 \mathrm{~cm}$ and heights between 8 and $20 \mathrm{~m}$ predominate. It is concluded that it is a relatively homogeneous forest, with typical elements of the Andean-Amazonian transition, whose vertical structure of the dominant flight is of the middle or sub-canopy, moderately dense, dominated by trees of Iriartea deltoidea Ruiz \& Pav., Alchornea latifolia Swartz, Hyeronima oblonga (Tul.) Müll. Arg. and Piptocoma discolor (Kunth) Pruski, those that have the greatest impact on its structure.

Keywords: Regeneration forests, dasometry, forest structure, diversity indices.
\end{abstract}

\section{INTRODUCTION}

Forests currently occupy $30.8 \%$ of the world's land surface (FAO and UNEP, 2020), and are considered a natural weapon against global warming due to their ability to mitigate climate change by reducing carbon emissions caused by deforestation and forest degradation (FAO, 2018); These effects have been considered as the causes of greatest impact on the conservation of biodiversity in Ecuador (LEÓN-YÁNEZ et al., 2011).

As reported by the Ministry of the Environment of Ecuador (2015), between 2008 and 2012 the deforestation rate in the country was $(0.65 \%), 65,880$ ha / year; The cited source states that said rate is lower than the one that had been determined for the period 2000 to 2008 (75,300 ha / year - 42\% less than in the previous period), as a result of the consolidation of property rights of the most important remaining forest areas.

One of the strategies implemented by Ecuador to conserve important forest areas has been the declaration of Protective Forests, a category established in the 2001 Forestry Law (MENDOZA, 2018).

In correspondence with this category is the Pindo Mirador Biological Station, owned by the Provincial Decentralized Autonomous Government of Pastaza, which has been declared with the purpose of conserving the forest ecosystem that protects the catchment of water from the Pindo Grande River basin, implemented several actions that favor conservation, highlighting the promotion of scientific research (LUZURIAGA; CUASAPAZ; QUICHIMBO, 2011). Recognizing the Strategy to Implement the Recommendations of the 
Pucallpa Proposal on the Sustainable Development of the Secondary Forest of the Amazon Region (TOLEDO, 1999) for which it is required to carry out basic scientific research oriented mainly to the knowledge of the dynamics of forests and successional stages.

In the Pindo Mirador Biological Station, studies were developed more than 10 years ago, characterizing sectors and components of the present ecosystem, and in particular inventories and other descriptions were carried out on the secondary forest, mainly in the Laguna Pindo sector, covering an area reduced sampling (LUZURIAGA, 2014).

Considering the above elements, with the present research was proposed as hypothesis: the forest siempreverde piemontano of Pindo viewpoint station has similarly is features in the structure and composition tree throughout its length and as objective characterize the tree structure of the forest siempreverde piemontano of the Pindo Mirador Biological Station, providing updated information that supports the conservation actions that are developed there.

\section{MATERIAL AND METHODS}

Biological Pindo viewpoint (EBPM) station has an area of 248 hectares located in Canton Mera Pastaza Province, Ecuador, between 1150 - 1300 meters above sea level (asl.). The average temperature varies between $18{ }^{\circ} \mathrm{C}$ and $24^{\circ} \mathrm{C}$, receiving rains that oscillate between 4,000 and 5,300 millimeters annually, being in one of the rainiest areas found in Ecuador.

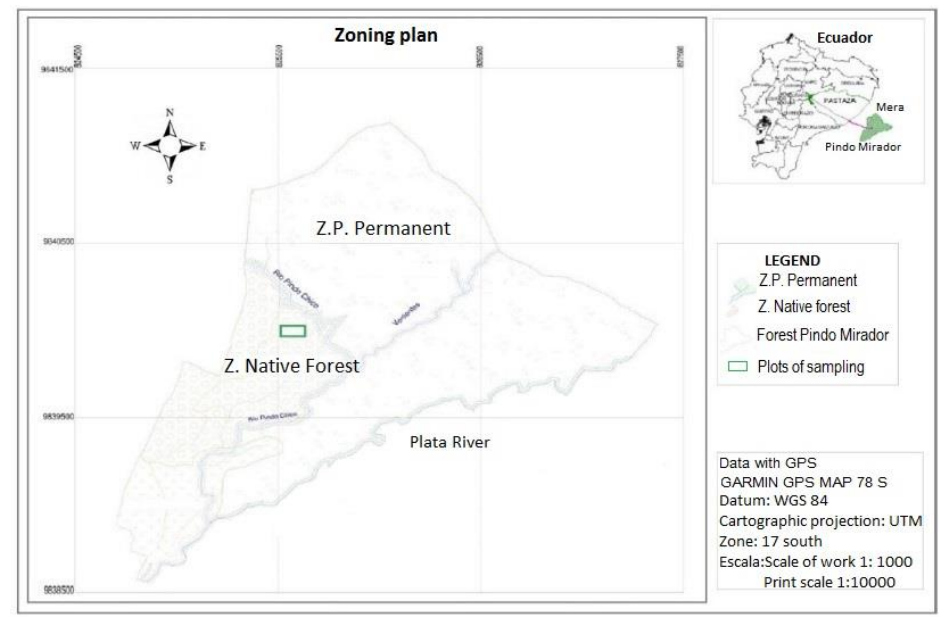

Figure 1. Location of the sampling plots of the evergreen piemontan forest of the Pindo Mirador Biological Station, Pastaza, Ecuador.

Figura 1. Localização das parcelas de amostragem da floresta perenifólia piemontana da Estação Biológica Pindo Mirador, Pastaza, Equador.

The territory is located in the northern biogeographic sector of the Eastern Cordillera of the Andes, where the evergreen Piedmont forest ecosystem occurs (MINISTERIO DEL AMBIENTE DEL ECUADOR, 2013). The sector where the sampling was applied within this successional stage is located between altitudes 1 $208 \mathrm{~m}$ above sea level. (coordinates S1 ${ }^{\circ} 26^{\prime} 42.11301$ "and W78 4'31.76349") and $1292 \mathrm{~m}$ asl. (coordinates $\mathrm{S} 1^{\circ} 26^{\prime} 45.81462$ "and W78\%4'31.4906").

Sample unit (n): 0.1 ha (20 X 50 m) following González-Oliva et al., (2017).

Sample size $(\mathrm{N}): 8$ plots of 0.1 ha $(0.8$ ha) representing $0.32 \%$ of the area overall.

Sampling design: systematic, with irregular separation between plots, $70 \mathrm{~m}$ for slopes greater than $45^{\circ}$ and 100 $\mathrm{m}$ for those less than $45^{\circ}$.

Field measurements: Species determination was made directly in the field; Those that it was not possible to determine in the area itself, samples or photographs of the key structures were taken, moving to collection conditions to be contrasted and to specify their determination with the support of specialized literature, Catalog of Vascular Plants of Ecuador (JORGENSEN; LEON-YANEZ, 1999) with the support of experts from the ECUAMZ Herbarium of the Amazonian State University. Both native and endemic species were identified using the Catalog of Vascular Plants of Ecuador (JORGENSEN; LEON-YANEZ, 1999), and those that have an assigned threat category, by the Red List of Ecuadorian Flora (LEÓN-YÁNEZ et al., 2011).

\section{Analysis of data}

The trunk diameters of all individuals were measured (including the standing dead, which were 
registered with the category of (Dry) that at a height of $1.30 \mathrm{~m}$ from the ground (D1.30) were $10 \mathrm{~cm}$ or more, Following Araújo et al., (2010); for this a caliper was used. Considering the criteria of Patiño et al., (2015), every tree whose base was found on the edge of the plot was taken into account as long as half or more than the basal area was within it.Each individual also had their absolute height (h) measured, using a Suunto Clinometer.

According to the observed frequency of species plus dead trees (Dry) by plots, Classes categories were granted, and with them a presence histogram was made according to Melo and Bargas (2003).

When evaluating the horizontal structure, the values of abundance, dominance, and relative frequency of each species were determined and with this the Index of Value of Importance of Species (IVIE) was calculated following Curtis and Macintosh (1951). As part of the horizontal structure, density (indiv / ha) and basal area $(\mathrm{G})$ were determined in $\mathrm{m}^{2}$ and in percentage, by species, according to the criteria of Patiño et al., (2015) also carrying out an analysis of the structure by diameter classes, establishing four intervals:

- Diameter class 1 (CD1): 10.0 a $19.9 \mathrm{~cm}$

- Diameter class 2 (CD2): 20.0 a $29.9 \mathrm{~cm}$

- Diameter class 3 (CD3): 30.0 a $39.9 \mathrm{~cm}$

- Diameter class 4 (CD4): $\geq 40.0 \mathrm{~cm}$ namely:

The individual height records of each tree registered in the plots were grouped into four ranges,

- Height range 1 (RH1): 2.00 a $7.99 \mathrm{~m}$

- Height range 2 (RH2): 8.00 a $13.99 \mathrm{~m}$

- Height range 3 (RH3): 14.00 a $19.99 \mathrm{~m}$

- Height range 4 (RH4): 20.00 a $25.99 \mathrm{~m}$

Using the statistical program PAST version 3.01 (HAMMER; HARPER; RYAN, 2001), the determination of diversity indices was carried out for the structural analysis of the forest mass, according to the criteria of Del Río et al., (2008) determining heterogeneity using the Shannon index (H); dominance through the Simpson index $(1-D)$ and fairness through the Uniformity Index $\left(\mathrm{Ev}_{-} \mathrm{e}^{\wedge} \mathrm{H} / \mathrm{S}\right)$. The number of species that would be expected in the tree community was also estimated using the $\bar{C}$ hao 2 index (SChao2), an analysis that allowed obtaining an evaluative criterion of the estimated tree diversity with respect to that observed in the sampling.

Given the observed variability of the abundance records of the trees measured in the plots, a transformation of the data was carried out for its standardization, using the square root, from which its descriptive statistics and graphic representation were evaluated. To evaluate whether or not it is possible to detect any significant differentiation of the records of abundance of trees for each of the established diameter classes, a non-parametric Kruskal-Wallis test was applied for the median by classes, whose results could support the analysis of the horizontal structure of the forest.

\section{RESULTS}

Species composition: 89 tree species belonging to 58 genera from 39 families were identified. Of the total five genera grouped the 23. 5 \% of species richness in the area, being Inga and Miconia gender reporting the highest record with six species each; three other genera (Nectandra, Ocotea and Virola) present three , 13 genera present two and the remaining 40 only with one species. The families with the highest representativeness in the sampling were Fabaceae with (nine species), Meliaceae, Melastomataceae, and Euphorbiaceae (seven species each), Lauraceae (six species), Myrtaceae (five species) and Rubiaceae with four species.

Of the total of species inventoried, two are endemic, Saurauia aequatoriensis Sprague and Nectandra coeloclada Rohwer, the same ones that are recognized as threatened species, according to León-Yanes et al., (2011).

The highest amount of tree species was obtained in Presence Classes I and II (Figure 2) with 41 and 27 species in each, in which abundances are recorded that is had in 66 and 107 individuals respectively, representing $2443 \%$ of the total sample, the most abundant species being Iriartea deltoidea with 85 individuals, followed by Alchornea latifolia with 42 individuals; The species that were present in 100\% of the samples, and therefore with Class V presence, were Piptocoma discolor, Turpinia occidentalis (Sw.) G. Don and Hyeronima oblonga. 


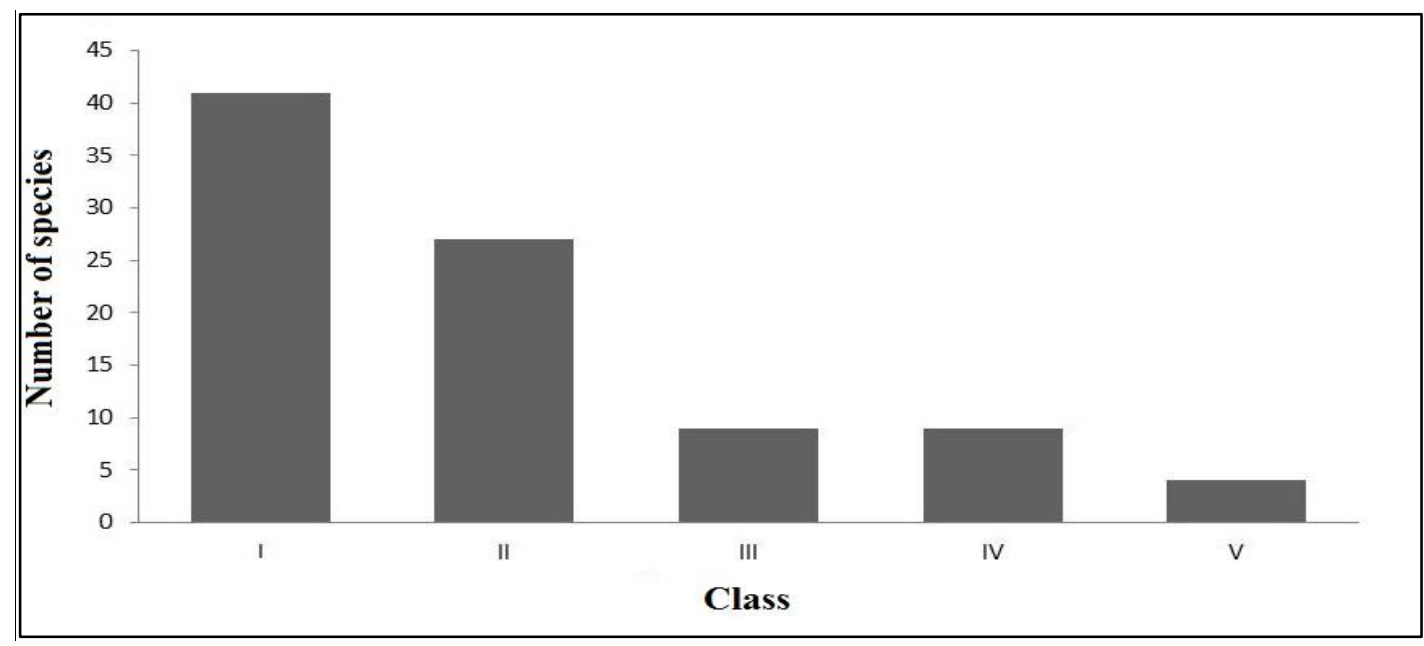

Figure 2. Histogram of presence with the number of species for each of the established Classes.

Figura 2. Histograma de presença com o número de espécies para cada uma das Classes estabelecidas.

The calculation of the Importance Value Index (IVI) of the species, 10 were the ones that obtained the highest percentage value (Table 1), three of them being those that, due to their value greater than $4 \%$, contribute more to the structure of the mass forest (Iriartea deltoidea, Alchornea latifolia and Turpinia occidentalis).

Table 1. Importance value of the 10 species with the greatest contribution to the structure of the forest at the Pindo Mirador Biological Station; The parameters that made up the analysis of the Importance Value Index (IVI) are shown, namely Relative Abundance (AR), Relative Frequency (FR) and Relative Density (DR).

Tabela 1. Valor de importância das 10 espécies com maior contribuição para a estruturação da floresta na Estação Biológica Pindo Mirador; São apresentados os parâmetros que integraram a análise do Índice de Valor de Importância (IVI), a saber, Abundância Relativa (AR), Frequência Relativa (FR) e Densidade Relativa (RD).

\begin{tabular}{lllcc}
\hline \multicolumn{1}{c}{ Species } & AR (\%) & $\begin{array}{c}\text { FR } \\
(\mathbf{\%})\end{array}$ & DR (\%) & $\begin{array}{c}\text { IVI } \\
(\mathbf{\% )})\end{array}$ \\
\hline Iriartea deltoidea Ruiz \& Pav. & 24.10 & 3.45 & 12.75 & 13.43 \\
Alchornea latifolia Swartz & 13.03 & 3.45 & 16.09 & 10.86 \\
Turpinia occidentalis (Sw.) G. Don & 3.58 & 3.45 & 7.10 & 4.71 \\
Hyeronima oblonga (Tul.) Müll. & 3.91 & 3.45 & 3.71 & 3.69 \\
Arg. & 5.21 & 2.59 & 1.67 & 3.16 \\
Wettinia maynensis Spruce & 3.58 & 3.45 & 2.16 & 3.06 \\
Viburnum ayavacense Kunth & 2.61 & 3.45 & 3.07 & 3.04 \\
Inga acreana Harms. & 2.28 & 3.45 & 3.39 & 3.04 \\
Pourouma cecropiifolia Mart. & 2.61 & 2.59 & 2.61 & 2.60 \\
Miconia splendens (Sw.) Griseb. & 1.30 & 2.59 & 3.29 & 2.39 \\
Cecropia angustifolia Trécul & & & & \\
\hline
\end{tabular}

Abundance: 710 tree individuals were surveyed in the eight sampling plots; this real abundance of the inventoried tree component represents a density of $885 \mathrm{indiv} / \mathrm{ha}$. In the distribution of abundances by plots Figure 3, atypical and extreme cases are observed, mainly due to the high abundances of the dominant species, which happens in the eight plots, however, those that exhibit the greatest variability are plots 7 and 8 . 


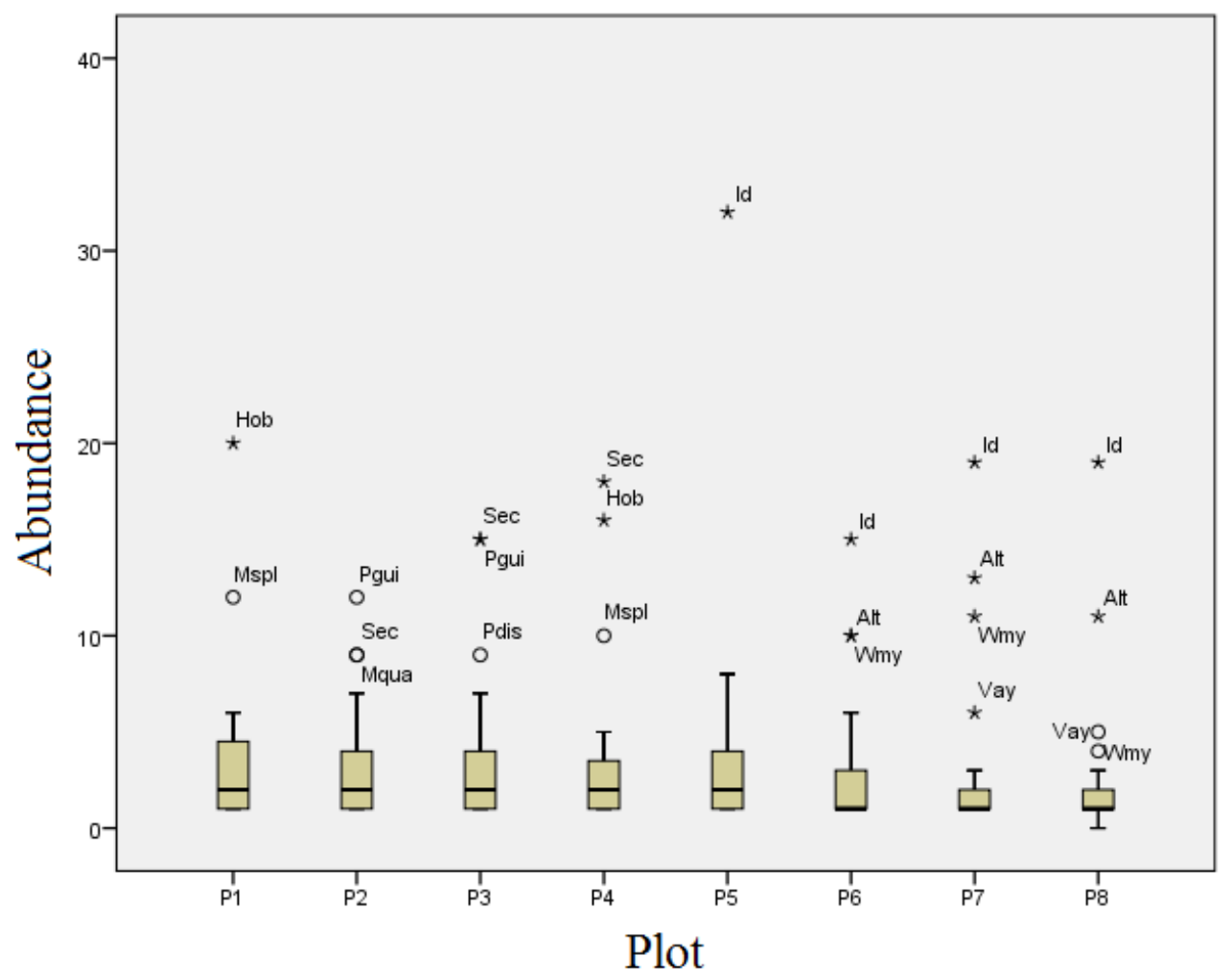

Figure 3. Distribution of abundance records by plot, after being transformed using the square root. Acronyms meanings: Sec (árbol seco), Hob (Hyeronima oblonga), Mspl (Miconia splendens Sw. Griseb), Pgui (Palicourea guianensis Aubl.), Mqua (Miconia quadripora Wurdack), Pdis (Piptocoma discolor), Wmy (Wettinia maynensis), Vay (Viburnum ayavacense), Alt (Alchornea latifolia), Id (Iriartea deltoidea).

Figura 3. Distribuição dos registros de abundância por parcelas, após serem transformados pela raiz quadrada. Significado das siglas: Sec (árvore seca), Hob (Hyeronima oblonga), Mspl (Miconia splendens Sw. Griseb), Pgui (Palicourea guianensis Aubl.), Mqua (Miconia quadripora Wurdack), Pdis (Piptocoma discolor), Wmy (Wettinia maynensis), Vay (Viburnum ayavacense), Alt (Alchornea latifolia), Id (Iriartea deltoidea).

Structural diversity of the forest mass: The values of diversity (Shannon Index_H), dominance (Simpson Index_1-D) and fairness (Species uniformity index_Ev), as expressions of the structural diversity of the forest mass according to Del Río et al., (2008), which were obtained for the sampled fragment are shown in (Table 2).

Table 2. Parcel values of the Shannon_H diversity index, Simpson dominance_1 - D and uniformity_Ev

Tabela 2. Valores por plotagem dos índices de diversidade de Shannon_H, dominância de Simpson_1 - D e uniformidade_Ev.

\begin{tabular}{lcccccccc}
\hline Index & Plot 1 & Plot 2 & Plot3 & Plot 4 & Plot 5 & Plot 6 & Plot 7 & Plot 8 \\
\hline Shannon_H & 2.491 & 2.881 & 2.743 & 2.706 & 2.529 & 2.997 & 3.022 & 3.139 \\
Simpson_1-D & 0.875 & 0.928 & 0.910 & 0.900 & 0.854 & 0.926 & 0.915 & 0.915 \\
Uniformidad_Ev_e^H/S & 0.603 & 0.713 & 0.621 & 0.623 & 0.545 & 0.641 & 0.555 & 0.623 \\
\hline
\end{tabular}

Structure by diameter classes: According to the four ranges established to define the diameter classes, it was observed that in the ecosystem there are more trees whose trunk diameters are between 10.0 and $20.0 \mathrm{~cm}$ of D1.30 (CD 1). In (Figure 4), the behavior of the mean abundance by diameter classes is shown, where the amount of trees with smaller diameter represents $59 \%$ of the total abundance that exists in this forest mass. Are significant differences in the observed variability of abundance classes according exposes the statistic of Kruskall-Wallis $(\chi 2=49.64 ; \mathrm{gl} \mathrm{3;} \mathrm{p}=0.000)$. 


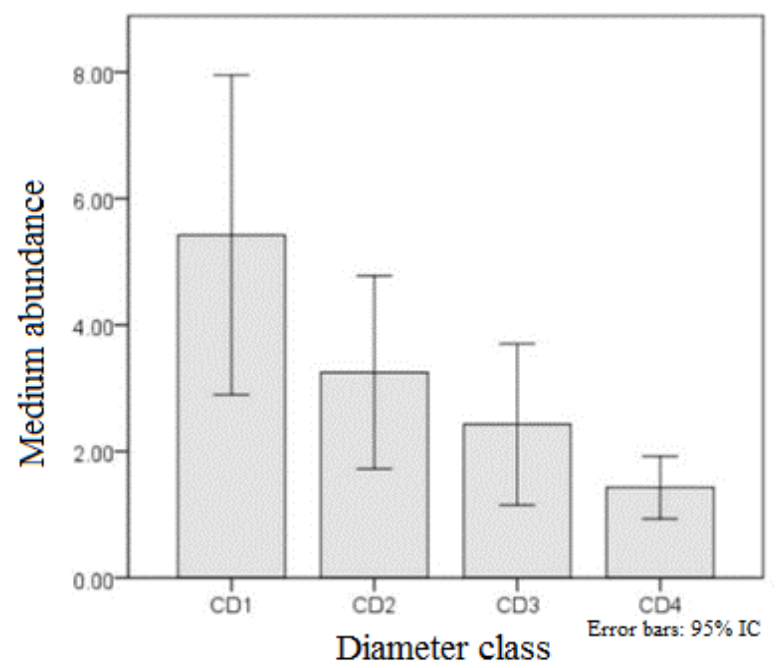

Figure 4. Distribution of the average tree abundance for each of the established Diameter Classes, where CD1 represents the range between 10.0 and $19.9 \mathrm{~cm}, \mathrm{CD} 2$ between 20.0 and $29.9 \mathrm{~cm}, \mathrm{CD} 3$ between 30.0 and $39.9 ; \mathrm{CD} 4 \geq 40.0 \mathrm{~cm}$.

Figura 4. Distribuição da abundância média de árvores para cada uma das Classes de diâmetro estabelecidas, onde CD1 representa a faixa entre 10,0 e $19,9 \mathrm{~cm}, \mathrm{CD} 2$ entre 20,0 e 29,9 cm, CD3 entre 30,0 e 39,9; CD4 $\geq$ $40,0 \mathrm{~cm}$.

Basal area: The determined basal area highlights the importance of eight species with values greater than $1 \mathrm{~m}^{2}$ Alchornea latifolia $3.28 \mathrm{~m}^{2}$, Iriartea deltoidea $2.42 \mathrm{~m}^{2}$, Piptocoma discolor $2.35 \mathrm{~m}^{2}$, Hyeronima oblonga 1 . $42 \mathrm{~m}^{2}$, Turpinia occidentali s $1.40 \mathrm{~m}^{2}$, Palicourea guianensis $1.39 \mathrm{~m}^{2}$, Cecropia angustifolia $1.34 \mathrm{~m}^{2}$ and Miconia splendens $1.20 \mathrm{~m}^{2}$, and with three species Miconia quadripora $0.66 \mathrm{~m}^{2}$; Inga acreana $0.58 \mathrm{~m}^{2}$ and Artocarpus altilis (Parkinson) Fosberg $0.58 \mathrm{~m}^{2}$ added to the eight mentioned above, represent $54.4 \%$ of the total basal area. The analyzes of this dasometric variable provide relevant information to understand how the tree assemblage fits into the horizontal structure of the forest, mainly to deepen the analysis of the present density.

Distribution tree ranges height: Greater abundance of tree counted was between 8 and $20 \mathrm{~m} \mathrm{(70.5 \%} \mathrm{total)}$ corresponding to the height ranges $\mathrm{RH} 2$ and $\mathrm{RH} 3$, of which are represented their means of abundance by ranges in (Figure 5).

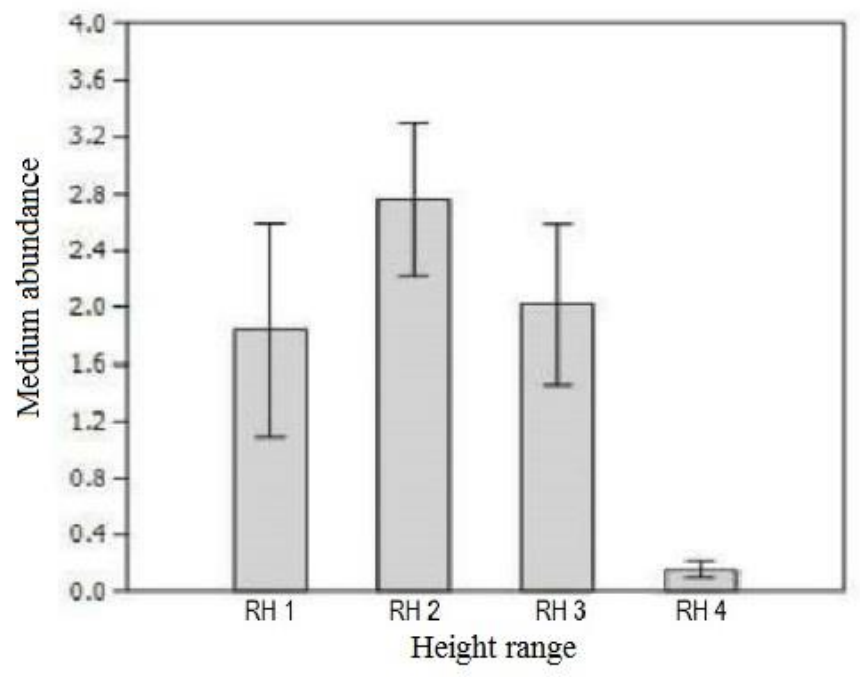

Figure 5. Distribution of the means of abundances for each height range established for the surveyed trees. The error bars represent $95 \%$ of the Confidence Interval.

Figura 5. Distribuição das abundâncias médias para cada faixa de altura estabelecida para as árvores censitárias. As barras de erro representam 95\% do intervalo de confiança. 


\section{DISCUSSION}

The results obtained regarding the composition of species and families of the identified trees (Table 1), coincide with those reported by Luzuriaga (2014) regarding the families with the highest species richness, which evaluated sectors of the same ecosystem, without However, in his case, Rubiaceae was the family with the highest records; there is also similarity with what Villacis et al. , (2017) who in two very close sectors (Mera and Shell), evaluating disturbed evergreen forests, detected coincidences in the dominance of Euphorbiaceae, Melastomataceae and Fabaceae mainly; as well as Maçaneiro et to the., (2014) in an e s tudio of fitosociología of a subtropical rain native forest in southern Brazil where the most representative families were Myrtaceae, Lauraceae and Fabaceae with the genera Ocotea, Myrcia and Eugenia, by Borgo et to the., (2011) in a forest ombrófilo dense reserve Natural of Rio Cachoeira in Antonina, Parana do NDEs reported as the best represented families were Myrtaceae, Fabaceae, Lauraceae, Melastomataceae and Rubiaceae, by Vieira et to the . (2014) in a forest ombrófilo dense altomontano of sier ra Capivar, who repor ta ron families Myrtaceae, Lauraceae and Melastomataceae as the largest absolute wealth of species, these similarities reinforce the view of the authors cited, about that These families constitute distinctive elements of the tropical humid forest with anthropic influence, characterized by elements of pioneer regeneration of rapid growth.

The low percentage of endemism observed in the flora may be associated with two fundamental factors; one related to the previous disappearance of selective logging species, another to the location of the ecosystem, typical of a transition between the lower Amazon and the Andean forest systems (MINISTERIO DEL AMBIENTE DEL ECUADOR, 2013), in this regard León-Yanes et al., (2011) report the endemism of the Ecuadorian Amazon around 10.7\%, however Jørgensen et al., (2011) refers that in Ecuador, the manifestation of endemism and quantity of threatened species, at heights between zero and $1000 \mathrm{~m}$ asl. It can fluctuate between 5 and $10 \%$ when analyzed comparatively with other Andean countries; this confirms that low percentages of endemism and threatened species is a typical characteristic of forest diversity; the other factor is related to the intense timber extraction to which the territory that the forest occupies today was subjected, as recognized by Luzuriaga et al., (2011).

The distribution of the frequencies in the presence histogram (Figure 2) highlights the heterogeneity of the vegetation revealed by the concentration of species in classes I and II. This distribution of the species according to their presence is cataloged by Melo and Bargas (2003), as an indicator of accentuated floristic heterogeneity. Species occupied the five classes of presence have been identified by others in the species composition of the forest siempreverde piemontano primary, in the same station Biological Pindo viewpoint (LUZURIAGA, 2014) and as close relatively areas province Napo (PATIÑO et al., 2015; TORRES et al., 2019); This confirms that the nearby matrix of primary forests, when the ecosystem is protected for its maintenance, contributes to its progressive successional dynamics. In the same way, the dead trees, identified as s echoes, had a high frequency, being present in all samples, which confirms what was stated by Del Río et al., (2008) regarding its importance in the contribution of nutrients to the forest system, contributing favorably to the aforementioned successional dynamics.

The primary forests around the station have contributed to the successional dynamics from the propagation of existing species of these forests, which have encountered environmental conditions due to the disturbances in the past with the opening of the canopy, the subsequent recovery of the soil, nutrient cycling s and the community of scatterers, I favored endo recruitment shade tolerant species. Classifying species into functional groups can answer these types of questions and contribute to understanding community assembly processes.

The 10 species that obtain the highest IVI value, as shown in (Table 2), are the ones that contribute the most to the structural conformation of this evergreen piemontane forest ecosystem, both due to the frequency of appearance and the abundance they observe, becoming the dominant of the arboreal component. This result coincides with that obtained by Luzuriaga (2014) in the same ecosystem, mainly with Miconia splendens and Cecropia angustifolia. We agree that these species absorb a large amount of nutrients, which means that they occupy more physical space in the forest and control a high percentage of energy that reaches the system.

Variability of records abundance shown in (Figure 3) confirms successional stage with a typical dynamic secondary forest, according to as have been set forth definitions for such post dynamic disturbances (FERRODIAZ; FERNANDEZ, 2013; TOLEDO, 1999). A comparative analysis with a previous study in this area does not provide conclusive information since Luzuriaga (2014) and Luzuriaga et al., (2011) assumed a greater range of variation of measurements, starting from the D1.30 of the individuals equal to or greater than $2.5 \mathrm{~cm}$, however, it is possible to confirm a higher density than other studies in similar ecosystems as seen in Villacis et al., (2017).

Regarding the structural diversity of this forest mass of forest, expressed through the value of the

Indices shown in (Table 3), it is observed that the Shannon Index behaves with similar values between the plots 6.7 and 8 , with plot 1 and 5 being less heterogeneous; This index gives great weight to the number of species 
present (MAGURRAN; MCGILL, 2011), and increases with increasing richness, taking higher values when the proportions of the different species are similar (DEL RÍO et al., 2008).

The values of the Simpson Index (Table 3) are close to 1 in almost all samples, reflecting the distribution of the number of species in proportions, giving it predictive value on the complexity of this forest mass (DEL RÍO et al., 2008). In the case of the uniformity of species in the forest fragment studied, the values shown in said Table 3 are intermediate between the range of 0 to 1 , except in plot 2, which is closer to 1; This confirms the aforementioned on the observed abundances, with a non-homogeneous distribution in the tree community, a criterion that is based on that described by Magurran and Mcgill (2011).

These indices provide relevant information for understanding the structural diversity of mixed stands (DEL RÍO et al., 2008); According to what was stated by Jost and González-Oreja (2012), their measures are related to the complexity of the community; In this case, the fragment under study has a complexity more influenced by the proportionality of species abundances (dominance) than by its richness.

The result shown in (Figure 5) on the distribution of abundance of arboreal by height ranges supports what Luzuriaga et al., (2011). They had reported for the analysis of the vertical structure of the forest in sectors of the study area itself, who found that $72.9 \%$ of the trees were in the height range between 10 and $20 \mathrm{~m}$.

\section{CONCLUSION}

- The evaluated forest has typical arboreal elements of the Andean-Amazon transition, where the complexity is more influenced by the proportionality of species abundances than by their richness.

- The Pindo Mirador Biological Station has a moderately high species richness, with few species that dominate due to their high abundances, moderately dense, whose predominant trees are trunks with diameters less than $20 \mathrm{~cm}$, and with a vertical structure of the dominant flight is the middle floor or sub-canopy.

- In the composition of ecosystem species, arboreal species of families widely represented in the Ecuadorian Amazon predominate, being richer in species of Fabaceae, Meliaceae, Melastomataceae, and Euphorbiaceae, highlighting Iriartea deltoinea, Alchornea latifolia and Turpinia occidentalis for their high dominance, frequency and abundance as the species with the greatest contribution to the structure of the forest stand.

\section{ACKNOWLEDGEMENTS}

To the University of Pinar del Río Hermanos Saiz Montes de Oca and the coordination of the Pindo Mirador Biological Station for supporting the scientific work developed.

\section{REFERENCIAS}

ARAÚJO, L.; ARAÚJO, F.; VILAR, S. Florística e estrutura de uma mata de terra firme na reserva de desenvolvimento sustentável rio iratapuru, amapá, Amazônia oriental, Brasil. Floresta, Curitiba, PR, v. 41, n. 1, p. 113-122, 2011.

BORGO, M, TIEPOLO, G.; REGINATO, M.; KUNIYOSHI, Y.S.; GALVÃO, F.; CAPRETZ, R L. ZWIENER V.P. Espécies arbóreas de um trecho de floresta atlântica do município de Antonina, Paraná, Brasil. Floresta, Curitiba, PR, v. 41, n. 4, p. $819-832,2011$.

CURTIS, J. T.; MCINTOSH, R. P. An upland forest continuum in the prairie-forest border region of Wisconsin. Ecology, Wisconsin, v. 32, n. 3, p. 476-496, 1951.

DEL RÍO, MONTES, F.; CAÑELLAS, I.; MONTERO, G. Revisión: Índices de diversidad estructural en masas forestales. Forest Systems, Madrid, v. 12, n. 1, p. 159-176, 2008.

FOOD AND AGRICULTURE ORGANIZATION OF THE UNITED NATIONS (FAO). El estado de los bosques del mundo - Las vías forestales hacia el desarrollo sostenible. Roma: 2018.58p.

FOOD AND AGRICULTURE ORGANIZATION OF THE UNITED NATIONS (FAO) y Programa de las Naciones Unidas para el Medio Ambiente (PNUMA). El estado de los bosques del mundo - Los bosques, la biodiversidad y las personas. Roma: 2020.224 .

FERRO-DIAZ, J.; FERNÁNDEZ, J. Post disturbance dynamic of canopy gaps in semideciduous tropical dry forest from Guanahacabibes peninsula, Cuba; its relation with the abundance of vascular epiphytes. Evaluation of state changes in degraded ecosystems in Ibero-America p. 200-213. 2013.

GONZALEZ-OLIVA, L. et al. Métodos de inventario, monitoreo y colecciones biológicas. AMA ed. La Habana, Cuba: 2017. 
HAMMER, Ø.; HARPER, D. A.; RYAN, P. D. PAST: Paleontological statistics software package for education and data analysis. Palaeontologia electronica, Copenhagen, v. 4, n. 1, p. 9, 2001.

JØRGENSEN, P. M. et al. Regional patterns of vascular plant diversity and endemism. Climate Change and Biodiversity in the Tropical Andes. Inter-American Institute for Global Change Research (IAI) and Scientific Committee on Problems of the Environment (SCOPE), p. 192-203, 2011.

JORGENSEN, P. M.; LEON-YANEZ, S. Catálogo de las plantas vasculares del Ecuador. Missouri Botanical Garden, 1999. v. 75

JOST, L.; GONZÁLEZ-OREJA, J. Midiendo la diversidad biológica: más allá del índice de Shannon. Acta zoológica lilloana, Tucumán, p. 3-14, 2012.

LEÓN-YÁNEZ, S. et al. Libro Rojo de Las Plantas Endémicas Del Ecuador, Segunda Edicion. Herbario QCA, Pontificia Universidad Católica del Ecuador, Quito, Ecuador, 2011.

LUZURIAGA, C.; CUASAPAZ, C.; QUICHIMBO, G. Inventario forestal en la estación Pindo mirador. Tsafiqui-Revista Científica en Ciencias Sociales, Mera, n. 2, p. 83-107, 2011.

LUZURIAGA, C. X. Inventario Florístico Del Bosque Que Rodea A La Laguna En La Estación Biológica Pindo Mirador Pastaza-Ecuador. Tsafiqui-Revista Científica en Ciencias Sociales, Mera, n. 6, p. 15-25, 2014.

MAGURRAN, A. E.; MCGILL, B. J. Biological diversity: frontiers in measurement and assessment. Oxford University Press, 2014.

MAÇANEIRO, J.P.; SEUBERT, R.C.; SCHORN, L.A. Fitossociologia de uma floresta pluvial subtropical primária no sul do brasil. Floresta, Curitiba, PR, v. 45, n. 3, p. 555 - 566, 2015.

MELO, O.A.; VARGAS, R. Evaluación ecológica y silvicultural de ecosistemas boscosos. Ibagué, Universidad del Tolima, p.55-56, 2003.

MENDOZA, Z. A. Biodiversidad Ecuatoriana. Universidad Nacional de Loja ed. Loja, Ecuador: 2018.

MINISTERIO DEL AMBIENTE DEL ECUADOR. Sistema de Clasificación de los Ecosistemas del Ecuador Continental. Subsecretaría de Patrimonio Natural ed. Ecuador: 2013.

PATIÑO, J.; LOZANO, P.; TIPÁN, C.; NABARRETE, H.; LÓPEZ, R.; ASANZA, M.; TORRES, B. Composición florística y estructura de un bosque siempreverde piemontano de 600 a $700 \mathrm{~m}$ snm en la cuenca del río Piatúa, Napo, Ecuador. Revista Amazónica Ciencia y Tecnología, Napo, v. 4, n. 2, p. 166-214, 2015.

TOLEDO, E. Estrategia para implementar las recomendaciónes de la propuesta de pucallpa sobre el desarrollo sosténible del bosque secundario en región Amazónica. Tratado de Cooperación Amazonica, Secretaría Pro Tempore, 1999.

TORRES, B.; VASSEUR, L.; LOPEZ, R.; LOZANO, P.; GARCÍA, Y.; ARTEAGA, Y.; BRAVO, C.; BARBA, C.; \& GARCIA, A. Structure and above ground biomass along an elevation small-scale gradient: case study in an Evergreen Andean Amazon forest, Ecuador. Agroforestry Systems, Madrid, p.1-11, 2019.

VIEIRA, R.S.; BLUM, C.T, VELLOZO, C. Caracterização florística e estrutural de uma floresta ombrófila densa altomontana na Serra do Capivari, Campina Grande Do Sul, Paraná. Floresta, Curitiba, PR, v. 44, n. 4, p. $565-576,2014$.

VILLACIS, H. G. S.; GARCÍA, Y.; GEADA, G.; ARTAEGA, Y.; RÍO, J.; GUERRERO, J. Efecto del grado de antropización en la estructura, en tres sitios fragmentados bosque siempreverde piemontano. CEFORES. Pinar del Río, v.5, n.2, p.172-180, 2017. 